\title{
YUN-JEONG KIM
}

\section{The mediating effect of basic vocational competency in the effect of self-esteem on job search skills of Korean middle-aged job seekers}

Introduction. Middle-aged Koreans are constantly looking for jobs in order to re-employ, despite the insecurity of declining job quality and wage levels. In order to be re-employed, it is necessary to improve job-search skills. As a way to improve job search skills, the focus was on job-seekers' self-esteem and basic vocational competency. The purpose of this study is to investigate the mediating effect of vocational competency in the effect of self-esteem on job search skills.

Study participants and methods. The participants in this study were 357 middle-aged job seekers aged 40 to 64 years old. $56.9 \%$ were women, $52.9 \%$ were in their 50 s and 60 s, and $46.2 \%$ were college graduates. $69.2 \%$ were married and $53.2 \%$ lived in small and mediumsized cities. By utilizing SPSS Win. 25.0 and PROCESS macro 3.5, descriptive statistics analysis, reliability analysis, correlation analysis, and mediating effect were analyzed.

Results. First, the higher the self-esteem, the higher the basic vocational competency $(r=.438$, $p<.001)$ and the job search skills $(r=.497, p<.001)$. The higher the basic vocational competency, the job search skills $(r=.699, p<.001)$ was high. Second, the effect of self-esteem on job search skills was .516 $(p<.001)$, but in the model with additional basic vocational competency, it was reduced to $.245(p<.001)$. Therefore, the mediating effect of basic vocational competency was verified.

Practical significance. It was revealed that self-esteem and basic job skills are important to improve the job-search skills of middle-aged adults. Therefore, in order to support customized career design at the national level, it is suggested that vocational education programs should include not only certification courses, but also content for improving basic vocational competency and counseling for improving self-esteem.

Keywords: self-esteem, basic vocational competency, job search skill, job seeker, mediating effect, Korean Middle-aged

\section{For Reference:}

Kim Yun-Jeong (2021). The mediating effect of basic vocational competency in the effect of selfesteem on job search skills of Korean middle-aged job seekers. Perspektivy nauki i obrazovania Perspectives of Science and Education, 53 (5), 560-568. doi: 10.32744/pse.2021.5.38 

[1]. According to Article 19 of the Korea's "Employment Promotion Act for the Elderly", the retirement age is ' 60 or older'. The average retirement age expected by workers was 53.8 [2], and the average retirement age felt by workers was 49.7 [3]. Nevertheless, the desire for re-employment among middle-aged and elderly people is higher than in other age groups. As the leading players in rapid growth and economic development, they regard stable income, a harmonious life with their family, and material prosperity as a successful life'. The middle and elderly in Korea are the generation who constantly seek jobs for reemployment despite the insecurity of lowering job quality and wage levels. Therefore, in this study, the focus of the study was on middle-aged job seekers who are unemployed and actively seeking jobs.

The skill that job seekers need most is job-seeking skills. This is because re-employment success leads to re-employment success by strengthening the will to get a job [4]. Job search skills consist of self-analysis ability, career mobility ability, and employment information management skills [5]. Self-analysis is the ability to re-recognize one's current situation, control one's actions to adapt to the situation, and effectively express oneself to other members of the organization. Career mobility ability is the use of relevant knowledge or skills to get a job or move. Employment information management skills refers to the ability to manage and utilize available information in consideration of one's personality and disposition by effectively accessing a variety of information. Job-seekers with high job search skills pursue active job searching activities as they are able to cope with job loss functionally.

Self-esteem has a positive effect on these job search skills. People who have a positive self-esteem are more likely to regain quality jobs through active job search activities by accepting life positively even in extreme situations of unemployment. Defrank and Ivancevich [6] reported that people with high self-esteem do not depreciate their values even in unemployment situations, and try to overcome unemployment with confidence that they are necessary for society. In addition, in previous studies [7-9], self-esteem was discussed as a psychological barrier for job search for the unemployed. Taking these preceding studies together, it is predicted that the self-esteem of job seekers will have a positive effect on job search skills.

Basic vocational competency are qualities that must be in common regardless of what role they play in all vocational activities due to globalization and rapid changes in the social economy [10-12]. Basic vocational competency is presented as 10 core competencies in Korea's NCS [13], and in SCANS in the United States, it is presented as basic competence, information processing ability, thinking ability, interpersonal skills, personality, resource utilization ability, and technical ability, British QODA added social and numeracy skills to the field of American SCANS [14]. In this study, the basic vocational competency was defined operationally as communication skills, numeracy skills, problem-solving skills, self-development skills, resource management skills, interpersonal skills, information skills, technical skills, organizational comprehension ability, and professional ethics suggested in Korea's NCS [13].

In this study, it was expected that basic vocational competency would play a role as a mediator in the effect of job seekers' self-esteem on job search skills. In order to verify the 
mediating effect of basic vocational competency, the relationship between self-esteem and job search skills, between self-esteem and basic vocational competency, and between basic vocational competency and job search skills must be proven. Since the causal relationship between self-esteem and job search skills was explained in the previous paragraph, it is necessary to consider related studies on the other two pathways. There were no studies have been found that have grasped the direct relationship between self-esteem and basic vocational competency. However, a significant number of positive relationships between self-esteem and the sub-factors of basic vocational competency have been published. For example, the higher the self-esteem, the higher the communication skills [15], the higher the problem solving ability [16], the higher the interpersonal skills [17], and higher professional ethics awareness [18]. Through this, it can be predicted that self-esteem will have an effect on basic job competency.

Lastly, many studies have been published that show that basic vocational competency have a positive effect on job search skills. In the era of the 4th industrial revolution, which is rapidly changing, the structure of the industry is becoming more complex, so human resources that can be flexibly applied to various fields are required. Therefore, most occupations tend to place importance on basic vocational competency such as communication skills and human relations skills in addition to specific professional skills [12], vocational basic competency is essential for enhancing competitiveness at the organizational level and an important factor in increasing employability at the individual level [19]. Therefore, the higher the basic vocational ability, the higher the job search skills for re-employment. Previous studies [20; 21] also reported that job-seekers' basic vocational competency had an effect on job search skills. Therefore, when these preceding studies are summarized, it can be predicted that the self-esteem of job seekers will affect job search skills by mediating basic vocational competency.

Therefore, the purpose of this study is to understand the mediating effect of basic vocational competency in the effect of self-esteem on job search skills for middle-aged job seekers aged 40 to 64 . Specifically, first, does the self-esteem of middle-aged job seekers affect job search skills? Second, does vocational basic competence have a mediating effect in these effects?

Methods

\section{Data collection procedure}

This study used data from Lee and others [21], "Lifelong Vocational Education and Training Plan for Employment Connections of middle-aged and older employment'." Lee and others [21] secured a total of 1,224 data through gender and age allocation among middle-aged people aged 40 to 64 who are willing to work. Surveys using the web and paper surveys were conducted simultaneously for one month in February 2020. In the study, data from 357 job seekers actively seeking jobs were used for analysis.

\section{Measurement}

The basic vocational competency was measured with 16 questions in 8 areas through revisions and supplements to the 2013 National Competency Standards and utilization package standards [13]. There were two questions for each area. For self-esteem, a 10-item 5-point Likert-type scale of Rosenberg [23] was used. The reliability of the scale is .912. The 
job search skills was an indicator developed by Lee et al. [21] based on previous research with 20-item 5-point Likert-type scale, after the consultation meeting, 9 reduced questions were used. The reliability of the scale is .879 .

\section{The social demographic characteristics of middle-aged people}

Among the 357 middle-aged job seekers, $43.1 \%$ were male and $56.9 \%$ were female, with a higher proportion of women. By age, $47.1 \%$ were in their 40 s and $52.9 \%$ were in their 50 s and $60 \mathrm{~s}$. College graduates accounted for the most at $46.2 \%$, and high school graduates accounted for $43.1 \%$. 'Married' was $69.2 \%$, 'unmarried' $17.4 \%$, 'divorced/dead/separated' $13.4 \%$ ('divorced' $9.0 \%$, 'dead' 2.2\%, 'separated' 2.2\%), the highest percentage of married people. In addition, $53.2 \%$ of residents in small and medium cities and $36.1 \%$ in large cities.

\section{Statistical Analysis}

By utilizing IBM SPSS24.0 and SPSS PROCESS macro ver.3.5, frequency, correlation, and SPSS PROCESS macro model 4 were analyzed.

Results

\section{Correlation between variables}

Table 1 shows the average (standard deviation) and correlation analysis of the selfesteem, basic vocational competency, and job search skills of middle-aged job seekers. Selfesteem is 3.490 out of 5 points, basic job skills are 3.640 points, and job search skills are 3.487 points. All three variables are high with the median value of 3 points or more.

In addition, all correlations between variables were significant. That is, the higher the self-esteem, the higher the basic vocational competency $(r=.438, p<.001)$ and the job search skills $(r=.497, p<.001)$ was high. The higher the basic vocational competency, the job search skills ( $r=.699, p<.001)$ was high. The correlation coefficient between basic vocational competency and job search skills was the highest at $r=.699$, so there is no problem of multicollinearity.

Table 1

Correlation between self-esteem, basic vocational competency and job search skills

\begin{tabular}{|l|c|c|c|}
\hline & Self-esteem & $\begin{array}{c}\text { Basic vocational } \\
\text { competency }\end{array}$ & Job search skills \\
\hline Self-esteem & 1 & & \\
\hline Basic vocational competency & $.438^{* * *}$ & 1 & 1 \\
\hline Job search skills & $.497^{* * *}$ & $.699 * * *$ & 3.487 \\
\hline Mean & 3.490 & 3.640 & .666 \\
\hline S.D & .641 & .712 & \\
\hline
\end{tabular}

$N=357 ; * * * p<.001$

2. The mediating effect of basic vocational competency in the effect of self-esteem on job search skills

To examine mediating effect of basic vocational competency in the effect of self-esteem on job search skills of Korean middle-aged job seekers, this study analyzed using Model 4 
of SPSS PROCESS macro suggested by Hayes [24]. The mediation effect was verified using bootstrap, the number of bootstrap samples was designated as 5,000, and the confidence interval was set to $95 \%$.

The self-esteem of middle-aged job seekers had a positive effect on job search skills. In other words, it was found that the higher the self-esteem, the higher the job-seeking skills of the job seekers $(\beta=.516, p<.001)$ (Table 2, Figure 1$)$.

Table 2

The effect of self-esteem on job search skills of middle-aged job seekers $(N=357)$

\begin{tabular}{|l|c|c|c|c|c|c|}
\hline \multicolumn{7}{|c|}{ Dependent : Job search skills } \\
\hline & Coeffect & SE & t-value & $p$ & LLCl & ULCl \\
\hline Constant & 1.686 & .170 & 9.932 & .000 & 1.353 & 2.020 \\
\hline Self-esteem & .516 & .048 & 10.777 & .000 & .422 & .610 \\
\hline R2 $=.247, F=116.151$ & $p=.000$
\end{tabular}

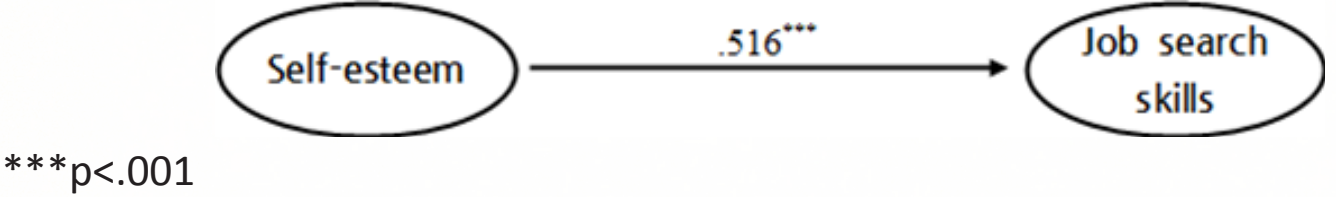

Figure 1 The effect of self-esteem on job search skills of middle-aged job seekers

Next, when analyzing the mediating effect of basic vocational competency in the effect of self-esteem of middle-aged job seekers on job search skills (Table 3, Fig. 2), the mediating effect for each path was statistically significant, and each model was also significant ( $F=$. $843, p<.001, F=202.063, p<.001)$. Self-esteem has a positive $(+)$ effect on basic vocational competency $(\beta=.488, p<.001)$, and basic vocational competency have a positive $(+)$ effect on job search skills $(\beta=.557, p<.001)$. In addition, the effect of self-esteem on job search skills was .516 (Table 2, Figure 1), but in the model with additional job-based skills, it was reduced to .245 (Table 3, Fig. 2). Therefore, the partial mediating effect of basic vocational competency was verified.

Table 3

The mediating effect of basic vocational competency in the effect of self-esteem on job search skills of middle-aged job seekers $(\mathrm{N}=357)$

\begin{tabular}{|c|c|c|c|c|c|c|}
\hline & Coeffect & SE & t-value & $\mathrm{p}$ & $\mathrm{LLCl}$ & ULCI \\
\hline \multicolumn{7}{|c|}{ Dependent : Basic job competency } \\
\hline Constant & 1.941 & .188 & 10.318 & .000 & 1.571 & 2.310 \\
\hline Self-esteem & .487 & .053 & 9.187 & .000 & .383 & .591 \\
\hline$R 2=.192, F=84.392, p=.000$ & & & & & & \\
\hline \multicolumn{7}{|c|}{ Dependent : Job search skills } \\
\hline Constant & .606 & .153 & 3.971 & .000 & .306 & .906 \\
\hline Self-esteem & .245 & .042 & 5.829 & .000 & .162 & .327 \\
\hline Basic vocational competency & .557 & .038 & 14.739 & .000 & .482 & .631 \\
\hline$R 2=.533, F=202.063, p=.000$ & & & & & & \\
\hline
\end{tabular}




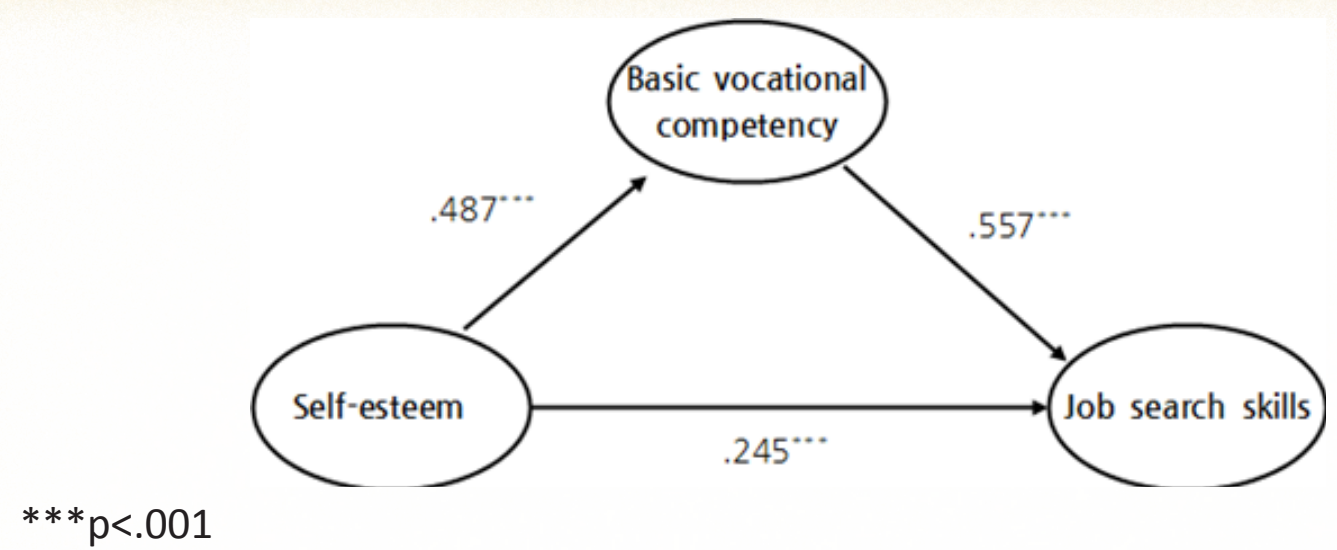

Figure 2 The mediating effect of basic vocational competency in the effect of self-esteem on job search skills of middle-aged job seekers

Finally, as a result of verifying the significance of the indirect effect of vocational basic ability in the relationship between self-esteem and job search skills of middle-aged job seekers, the effect of basic vocational competency was .271, and Boot SE was .038. In addition, there was no zero between $\mathrm{LLCl}$ and ULCI (Table 4). Therefore, it can be seen that the mediating effect of basic vocational skills is significant.

Table 4

Indirect effect of self-esteem on job search skills ( $N=357)$

\begin{tabular}{|l|c|c|c|c|}
\hline & Effect & BootSE & BootLLCl & BootULCI \\
\hline $\begin{array}{l}\text { Basic vocational } \\
\text { competency }\end{array}$ & .271 & .038 & .200 & .350 \\
\hline
\end{tabular}

The purpose of this study was to investigate the mediating effect of basic vocational competency in the effect of self-esteem on job search skills, targeting middle-aged people aged 40 to 64. Data from Lee and others [22] were used. Lee and others [22] finally obtained a total of 1,224 people through a sampling of the middle-aged people who are willing to have a job by gender, age, and occupation. In this study, the data of 357 job seekers who are actively seeking employment were used for analysis. The discussions and suggestions are as follows while summarizing the main research results.

First, the higher the self-esteem of middle-aged job seekers, the higher their job search skills. These results support a previous study [7-9]) that self-esteem affects job search skills.

Second, it was found that basic vocational competency mediates the effect of middleaged job seekers' self-esteem on job search skills. In other words, it was found that the higher the self-esteem of the Korean middle-aged, the better the basic vocational competency, and the improved basic vocational competency improved job search skills. These results are in the same context as those of previous studies that revealed the relationship between self-esteem and basic vocational competency [15-17], basic vocational competency and job search skills [5; 20].

In the case of middle-aged Koreans, the meaning of a job in a successful life is high, and as a result, they repeat employment and retirement several times before reaching 
full retirement. So, the job search skills of the middle-aged are important not only in their work life but also throughout their life. As a result of this study, it was found that the self-esteem and basic vocational competency of middle-aged job seekers contribute to improving job search skills. When self-esteem is high, the intensity of the unemployment shock is low and the duration is short, so job search for re-employment is carried out within a short period of time after unemployment [6]. In addition, the self-esteem of the unemployed tends to deteriorate up to about 6 months after unemployment, and then recover again after about a year [8]. Therefore, it is suggested that it is necessary to help restore self-esteem in a shorter time by providing an educational program that improves job-seeking efficacy and self-esteem for job-seeking at a time when self-esteem deteriorates immediately after unemployment.

In addition, it has been found that the role of self-esteem is also important in improving the job search skills of the middle and old, but the basic vocational competency play a mediating role. The mediating effect of basic vocational competency has not been directly studied so far, but the results of this study revealed that basic vocational competency play a mediating role in the effect of middle-aged workers' self-esteem on job search skills. Therefore, it is also necessary to improve job-seeking skills by improving job-seeking skills. This is because, above all, basic vocational skills are related not only to improvement of job search skills but also to re-employment [25]. In other words, in the study of Cho [25], although it was a study targeting university graduates, employed persons had higher subfactors of basic vocational competency (numerical ability, problem solving ability, selfdevelopment ability, organizational understanding ability, and interpersonal relationship ability) than unemployed.

Therefore, basic vocational competency should be included as a core content of vocational education for the middle-aged, but the current vocational education programs for the middle-aged are more focused on certification courses and professional skills improvement. Unemployment and re-employment can be repeated at any time after middle-aged, and there is a high possibility of working in a job that is not similar to the previous job. Therefore, it is necessary to improve basic vocational basic skills for reemployment of middle-aged job seekers.

The third phase of life in the "education - work - retirement" phase collapsed due to changes in social and occupational environment such as the 4th Industrial Revolution and the aging society. As a result, they will have two or three different jobs throughout their lives, and re-education will be needed to learn new skills. Therefore, in order to support customized career design at the national level, it is suggested that vocational education programs should include not only certification courses, but also content for improving basic vocational competency and counseling for improving self-esteem.

However, the meaning given by a job may differ between men and women, and may differ according to the characteristics of the job type, but this study did not consider these variables. In future research, it is necessary to develop and analyze a research model that considers gender and occupational differences.

Acknowledgment

This study was done with the support of research grant in 2021 from Hanseo University. 
1. Lee, H. S. (2019). A Study on the effect of new middle-aged human capital and social capital on the will to reemployment after retirement: Focusing on the mediating effect of positive psychological capital and the moderating effect of job-seeking skill. [Dissertation][Seoul]: Ka-Chun University. Retrieved from: http://www.riss.kr.library. hanseo.ac.kr:8000/search/detail/DetailView.do?p_mat_type=be54d9b8bc7cdb09\&control_no=3610f27b8ab4e7 99ffe0bdc3ef48d419

2. Recruit Times (2020). The average retirement age of 2020 employees is 53.8. Retrieved from: http://www. recruittimes.co.kr/news/articleView.html?idxno=88031, 2021.8.09.

3. dong A.com (2020). Average age of retirement experienced by workers is 49.7 years old. Retrieved from: https:// www.donga.com/news/Economy/article/all/ 20200911/102887337/1

4. Snyder, M. (1974). Self-monitoring of expressive behavior. Journal of Personality and Social Psychology, 30(4), 526537. DOI: 10.1037/h0037039

5. Latham, V. M. (1985). The role of personality in the job search process, Paper presented at the annual meeting of the Mid-western Psychological Association. 57th, Chicago, II, May 2-4. Retrieved from: https://eric. ed.gov/?id=ED259247

6. DeFrank, R. S., \& Ivancevich, J. M. (1986). Job loss: An individual level review and model. Journal of Vocational Behavior, 28(1), 1-20. DOI: 10.1016/0001-8791(86)90035-7

7. Creed, P. A., Hicks, R. E., \& Machin, M. A. (1998). Behavioral plasticity and mental health outcomes for long-term unemployed attending occupational training programmes. Journal of Occupational and Organizational Psychology, 71(2), 171-191. DOI:10.1111/j.2044-8325.1998.tb00671.x

8. Ahn, S. S., Shin, K. H., Han, Y. S., Tak, J.K., Yoo, T. Y., Han, T. Y., Hwang, J.O. (2005). Gender differences in responses to unemployment and job search intensity. The Korean Society of Women Psychology, 10(3), 375-404. Retrieved from: https://www.dbpia.co.kr/journal/articleDetail?nodeld=NODE06371976

9. Choi, K. H., Tak, J. K. (2017). The effects of a group coaching program focusing strengths on self-esteem, job Search efficacy, and resilience for career discontinued women. The Korean Journal of Coaching Psychology, 1(1), 73-97. DOI:10.51457/kjcp.2017.06.1.1.73

10. Park, D. Y., Ju, I. J., Jin, M. S., Choi, S. A. (2010). The development of core competency model using a Delphi technique. Korea Research Institute for Vocational Education and Training, 29(4), 349-385. Retrieved from: https:// www.dbpia.co.kr/Journal/articleDetail?nodeld=NODE09049249

11. Field, J., \& Schuller, T. (2000). Networks, norms and trust: explaining patterns of lifelong learning in Scotland and Northern Ireland. Differing Visions of the Learning Society. Research Findings, 2, 95-118. Retrieved from: https:// books.google.co.kr/books?hl=ko\&lr=\&id=Cd41DwAAQBAJ\&oi=fnd\&pg=PA95\&dq=Field

12. Lee, J. P., Park, Y. H., Hong, S. Y., Na, S., \& Lee, B. W. (2004). Surveys on adult basic workplace skills programs, 1st Ed. Sejong: Korea Research Institute for Vocational Education and Training.

13. NCS (2020). Basic vocational competency. Retrieved from: https://www. ncs.go.kr/th03/TH0302List.do?dirSeq=121.

14. Lee, J. P. (2005). A comparative analysis on good practices for developing basic workplace skills for university students in selected countries. Korea Journal of Comparative Education, 15(2), 171-195. Retrieved from: http:// scholar.dkyobobook.co.kr.library.hanseo.ac.kr:8000/searchDetail.laf?barcode=4010017241493\#

15. Lin, Y. R., Shiah, I. S., Chang, Y. C., Lai, T. J., Wang, K. Y., \& Chou, K. R. (2004). Evaluation of an assertiveness training program on nursing and medical students' assertiveness, self-esteem, and interpersonal communication satisfaction. Nurse education today, 24(8), 656-665. DOI: 10.1016/j.nedt.2004.09.004

16. Baik, E. J. (2020). The associations among early childhood pre-service teachers self-esteem, self-worth, and social problem solving. Korean Journal of Early Childhood Education, 22(1), 93-110. DOI: 10.15409/riece.2020.22.15

17. Murray, S. L., Holmes, J. G., \& Collins, N. L. (2006). Optimizing assurance: The risk regulation system in relationships. Psychological bulletin, 132(5), 641-666. DOI: 10.1037/0033-2909.132.5.641

18. Kim, S. S., Lee, J. S., Kim. E. J., Lee, W. H., Jung, E. S., Cheon, S. J. (2012). Influence of mountain bike commissaire' stress upon professional ethics and self-Esteem. The Korean Journal of Sports, 10(2), 13-21. Retrieved from: https:// www.earticle.net/Article/A177642

19. Park, J. H., Lee, J.P., Park, Y. H. (2013). A study on the needs assessment of key competencies from industries for graduates of Korea polytechnic colleges. The Journal of Vocational Education Research, 32(1), 83-105. Retrieved from: http://www.riss.kr/link?id=A104015240

20. Song, Z., Wanberg, C., Niu, X., \& Xie, Y. (2006). Action-state orientation and the theory of planned behavior: A study of job search in China. Journal of Vocational Behavior, 68(3), 490-503. DOI: 10.1016/j.jvb.2005.11.001

21. Boswell, W. R., Zimmerman, R. D., \& Swider, B. W. (2012). Employee job search: Toward an understanding of search context and search objectives. Journal of Management, 38(1), 129-163. DOI: 10.1177/0149206311421829

22. Lee, S. J., Yang J. S., Song, K.W., Kim, Y.J. (2020). Lifelong vocational education and training plan for connections middle-aged and older employment. Sejong: Korea Research Institute for Vocational Education and Training. 
23. Rosenberg, M. (1965). Rosenberg self-esteem scale (RSE). Acceptance and commitment therapy. Measures package, 61. Retrieved from: http://www. integrativehealthpartners.org/downloads/ACTmeasures.pdf\#page=61

24. Hayes, A. F. (2018). Partial, conditional, and moderated moderated mediation: quantification, inference, and interpretation. Communication Monographs, 85(1), 4-40. DOI: 10.1080/03637751.2017.1352100

25. Choi, H. Y. (2018). The relationships between vocational key competencies and college graduate employment- $A$ case of K College. Korean Journal of General Education, 12(6), 245-265. Retrieved from: http://www.dbpia.co.kr/ journal/articleDetail?nodeld=NODE07587880

\author{
Information about the author \\ Yun-Jeong Kim \\ (South Korea, Seosan city) \\ Doctor of Humanities, Professor \\ Department of Health, Counseling and Welfare \\ Hanseo University \\ E-mail: twoyun21@hanmailnet \\ ORCID ID: 0000-0001-7707-8330
}

